\title{
Functional Physical Training Program for Revised Physical Fitness Test of Korean Police Officers
}

\author{
Ji Heon Chae' ${ }^{1}$, Hyun-Joo Kang ${ }^{1}$ \\ ${ }^{1}$ Department of Sports Medicine, Soonchunhyang University, Asan, Republic of Korea
}

Received: December 20, 2021

Accepted: January 5, 2022

Published online: January 31, 2022

Keywords:

Functional Physical Training

Police Officer

Revised Physical Fitness Test

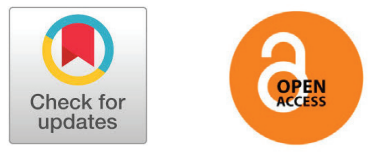

\section{ABSTRACT}

OBJECTIVES Police officers need to maintain and improve their physical fitness in order to properly operate on the duty and ensure their own safety. A problem was raised to prepare an improvement plan according to the current status and problems of physical fitness test of the Korean police officer. Accordingly, a revised physical fitness test for new police officers will be introduced from 2023 and will be fully introduced from 2026. The purpose of this study is to introduce revised physical fitness test type including professional physical element proper for duty feature to secure the security power and physical training program for the revised physical fitness test for Korean police officers.

METHODS Functional physical training program consisted of combined with health-related fitness factors and skill-related fitness factors for successfully cope with their duties which involve physical tasks. FITT principles of functional physical training program were made for circulated physical fitness test for new Korean police officers.

CONCLUSIONS Police officers must be physically fit to successfully cope with their duties which involve physical tasks. The functional physical training program could help new Korean police officers maintain physical fitness including cardiorespiratory fitness, muscular fitness, agility, could be prevent a decline in performance physical capacity and occupational duties.

() The Asian Society of Kinesiology and the Korean Academy of Kinesiology

\section{연구 필요성}

경찰공무원은 국민의 자유와 권리를 보호하고 사회 공공의 질서를 위하여 치안유지와 범죄의 예방 및 진압 등의 직무를 수행한다[1]. 2020년 한 해에 살인, 강도, 강간 및 강제추행, 절도, 폭력 등 5 대 범죄를 포함하여 총 $1,587,866$ 건의 범죄가 발생했다[2]. 이러한 근무 현 장에서 경찰공무원은 경찰 장구를 착용한 채 밤낮없이 버틸 수 있는 강인한 체력과 긴급상황에 대처할 수 있 는 신체 능력이 요구된다[3]. 경찰공무원은 다양한 범 죄현장에서 범법자를 제압하기 위한 근력, 범법자 추격 등에 필요한 심폐지구력과 근지구력, 현장에서 흉기를

*Correspondence: Hyun-Joo Kang, Department of Sports Medicine, Soonchunhyang University, Soonchunhyang-ro, Asan-si, Republic of Korea; Tel: +82-41-530-1114; E-mail: violethjk@naver.com
피하는 등 순간적으로 신체를 이동해야 하는 순발력과 민첩성 등 절대적인 체력이 필요하다[3, 4]. 방훈식[5] 은 경찰공무원의 활동에서 실제로 발생할 수 있는 상황 을 대비하기 위해 민첩성과 지구력 훈련이 중요하다고 보고하였다. 또한 Silk 등[6]도 높은 근력과 힘을 요구 하는 범법자 제압과 체포 등이 신체적으로 가장 부담이 되는 업무이며, 이 외에도 근지구력과 심폐지구력이 경 찰공무원에게 필요한 주요 체력 요인임을 밝혔다.

경찰공무원 채용과 경찰 간부후보생 선발을 위해 필 기시험과 신체검사를 거쳐 체력 수준을 평가를 하는 체 력검사 시험을 필수로 실시하고 있다[7]. 체력검사는 돌 발적인 위험상황이나 범죄현장에서 전문적인 운동능력 을 실질적으로 요구하는 체력 중심의 평가라 할 수 있다. 경찰공무원의 전반적인 신체 능력을 살펴본 Bonneau 
와 Brown[8]도 경찰공무원의 체력검사는 직무 수행과 관련 있어야 하며, 신체능력을 합리적으로 유지할 수 있 어야 한다고 주장했다.

현재 시행되는 경찰공무원 채용을 위한 체력검사 시 험의 평가 기준과 방법에 따르면, 신임 경찰공무원 채용 체력검사는 $100 \mathrm{~m}$ 달리기, $1,000 \mathrm{~m}$ 달리기, 윗몸일으키 기, 좌우 악력, 팔굽혀펴기로 총 5 개의 종목이 실시되 고, 경찰 간부후보생 선발을 위한 체력검사 시험은 $50 \mathrm{~m}$ 달리기, 왕복오래달리기, 윗몸일으키기, 좌우 악력, 팔 굽혀펴기 총 5 개의 종목으로 운영되고 있다[9]. 하지만 기존의 체력검사 시험은 경찰공무원의 직무 수행 능력 을 평가하는 기본 요건을 충족하지 못하고, 검사 방법 의 실효성과 기준이 현저하게 낮다는 비판적인 여론이 보고되었다[10]. 김한배, 김은정 [11]도 기존 시행하고 있는 체력검사 종목이 실제 치안 현장에서 범법자의 예 측 불가한 돌발 상황에 신속하게 대처하고 검거하는데 부적합하다고 주장했다.

이러한 비판적인 여론과 전문가들의 의견에 따라 2023년부터 경찰공무원 채용을 위한 개정된 체력검사 시험이 일부 도입되며, 2026년부터 전면 도입될 예정이 다. 현행 기초체력 위주로 편성된 체력검사 대비 새로 편 성된 체력검사 선발 기준은 경찰공무원의 직무와 관련 된 체력검사 요소를 병합하여 측정하는 형태로 타당한 방법이라 평가되고 있다[10]. 따라서 본 연구의 목적은 국내 새롭게 도입되는 경찰공무원 채용을 위한 체력검 사 시험 방법과 국외 체력검사 시험에 대한 소개 및 궁 극적으로는 경찰공무원이 개정된 체력검사 시험에 통과
될 수 있도록 기능성 체력 훈련 프로그램을 제공하여 직 무에 최적화된 인재를 선발하는데 도움을 주고자 한다.

\section{한국의 경찰공무원 채용을 위한 개정된 순환 식 체력검사}

2023년부터 경찰대학생, 간부후보생 선발과 경찰행 정학과 경력 채용 시험에 우선 시행되며, 2026년부터 모 든 경찰시험에 개정되는 순환식 체력검사가 도입될 계 획이다. 우리나라에서 새롭게 도입되는 순환식 체력검 사에 대한 내용은 <Table 1 >과 같다.

시행 예정인 순환식 체력검사 시험은 모든 체력검사 항목에서 현장 경찰공무원의 장구 무게인 $4.2 \mathrm{~kg}$ 의 조끼 를 착용한 채로 단계별로 체력검사가 진행된다. 1 단계 장애물 코스 달리기는 범법자 추격 및 현장 출동과 같은 긴급한 상황에 대처하기 위해 개발된 종목으로, 스피드 와 방향 전환 및 순발력을 측정한다. 매트, 계단, 허들과 같은 장애물이 설치된 약 $340 \mathrm{~m}$ 의 코스를 6 회 반복하여 달리며, 이때 1 회 코스 완주 후 $1.5 \mathrm{~m}$ 의 장벽을 넘고 나 머지 5 회의 코스를 반복하여 완주하도록 한다. 2 단계 장 대 허들넘기는 장시간 또는 야간근무를 하는 경찰공무 원이 효율적인 업무 수행을 위해 필수적으로 필요한 코 어 근력을 측정하기 위해 개발된 검사이며, $0.9 \mathrm{~m}$ 높이 의 장대 허들을 손으로 짚고 넘어 엎드린 후 일어나 다 시 장대를 넘고 누웠다가 일어나는 동작을 3 회 실시한 다. 3 단계 신체 저항 테스트인 밀기-당기기 검사는 범 법자를 제압하거나 범법자의 행패 등을 방어하고 대처

Table 1. New police officer recruitment physical fitness test in Korea

\begin{tabular}{|c|c|c|c|}
\hline Stage & \multicolumn{2}{|c|}{ Physical fitness test } & \multirow{2}{*}{$\begin{array}{l}\text { Evaluation standard } \\
\text { - Repeat the designated course } 6 \text { times. } \\
\text { - (1) Running (2)Mat jump (3)Stair climb (4) Hurdle jump } \\
\text { - After finishing the first lap, perform the (5) Barrier surmount only once, followed by the remaining } 5 \text { laps. } \\
\text { - If the section is successful, move on to the next section. } \\
\text { - Climb the stairs one by one. }\end{array}$} \\
\hline 1 & $\begin{array}{l}\text { Obstacle } \\
\text { course } \\
\text { running }\end{array}$ & $\begin{array}{l}\text { (1) Running } \\
\text { (2) Mat jump } \\
\text { (3) Stair climb } \\
\text { (4) Hurdle jump } \\
\text { (5) Barrier surmount }\end{array}$ & \\
\hline 2 & \multicolumn{2}{|c|}{$\begin{array}{l}\text { Vault jmp } \\
\text { (0.9m Railing) }\end{array}$} & $\begin{array}{l}\text { - Repeat } 3 \text { times. } \\
\text {-When lying on the stomach, chest, shoulders, and thighs should touch the floor accurately. } \\
\text {-When lying down, the shoulders, back, hips, and back thighs should touch the floor accurately. }\end{array}$ \\
\hline 3 & \multicolumn{2}{|c|}{$\begin{array}{l}\text { Physical restraint } \\
\text { (Push and pull) }\end{array}$} & $\begin{array}{l}\text { - Repeat } 3 \text { times each. } \\
\text { - Movement while drawing a semicircle with the push and pull of Physical Resistant equipment } \\
\text { completely. }\end{array}$ \\
\hline 4 & \multicolumn{2}{|c|}{ Victim rescue } & $\begin{array}{l}\text { - Turn around without touching the cone at the turning point. } \\
\text { - Drag a } 72 \mathrm{~kg} \text { mannequin along at } 10.7 \mathrm{~m} \text {. }\end{array}$ \\
\hline 5 & \multicolumn{2}{|c|}{ Trigger pull } & $\begin{array}{l}\text { - Holds the firearm within a } 23 \mathrm{~cm} \text { diameter metal ring and pulls the trigger of an unloaded firearm } 16 \\
\text { times with the dominant hand, then } 15 \text { times with the non-dominant hand. }\end{array}$ \\
\hline
\end{tabular}


할 수 있는 근체력을 측정하기 위한 목적으로 개발되었 으며, $32 \mathrm{~kg}$ 의 저항성 기구를 밀고 당기는 것을 각 3 회 씩 진행한다. 4 단계 구조하기는 물건이나 부상자 등을 안전한 곳으로 이동시키는 상황을 반영한 전신 근력을 평가하기 위한 목적으로 개발된 종목이며, $72 \mathrm{~kg}$ 의 모 형 인형에 설치된 줄을 잡고 당겨 $10.7 \mathrm{~m}$ 의 거리를 이 동한다. 5단계 방아쇠 당기기는 범법자를 제압하는 등 의 상황에서 테이저 건 등 총기를 격발할 수 있는 상지 근력과 악력을 측정하기 위한 목적으로 개발된 종목이 며, 직경 $23 \mathrm{~cm}$ 의 원 안에서 주 사용 손은 16 회, 비 주 손은 15 회 방아쇠를 당기는 것을 평가한다. 새롭게 도 입되는 체력검사 시험에서는 남녀가 구별이 없이 동일 한 기준으로 적용하여 5단계 코스를 연속으로 수행한 남녀가 동일한 기준 시간인 4 분 40 초 이내를 통과하면
된다. 과거 종목식 체력검사에 비해 순환식 체력검사는 장애물과 장대 넘기, 범인 추격, 피해자 구조, 밀기와 당 기기, 테이저 건 격발 등 경찰공무원의 현장 직무에 적 합한 형태로 변경되어 순환식 체력검사 시험에 통과한 경찰공무원들은 국민의 생명과 재산을 지키는 치안 업 무 수행 능력과 체력을 갖춰 직무를 보다 원활하게 수 행해 나갈 것으로 판단된다.

\section{국외의 경찰공무원 채용 체력검사 제도}

외국 경찰공무원 채용 시 체력검사에 대한 사례를 살 펴보면, 넓게는 국가별로, 좁게는 도시별로 다르게 적용 하고 있다. 아직 많은 나라에서 종목식 체력검사를 실 시하고 있으나, 미국과 캐나다 등의 선진국에서는 현장

Table 2. New police officer recruitment physical fitness test in other countries

\begin{tabular}{|c|c|}
\hline Section & Contents \\
\hline $\begin{array}{l}\text { The United } \\
\text { States } \\
\text { NYPD }\end{array}$ & $\begin{array}{l}\text { 1. Barrier surmount - sprinting } 15 \mathrm{~m} \text { and surmounting a } 1.8 \mathrm{~m} \text { barrier. } \\
\text { 2. Stair climb - go over and back stairs two times. } \\
\text { 3. Physical restraint simulation - demonstrating the ability to physically restrain someone. Push and pull } 4 \text { times each. } \\
\text { 4. Pursuit run - running the } 182 \mathrm{~m} \text { designated course. } \\
\text { 5. Victim rescue - drag a } 72 \mathrm{~kg} \text { mannequin along at } 10.7 \mathrm{~m} \text {. } \\
\text { 6. Trigger pull - holds the firearm within a nine-inch diameter metal ring and pulls the trigger of an unloaded firearm } 16 \text { times with the } \\
\text { dominant hand, then } 15 \text { times with the non-dominant hand. }\end{array}$ \\
\hline $\begin{array}{l}\text { Canada } \\
\text { RCMP }\end{array}$ & $\begin{array}{l}\text { 1. Obstacle course station } \\
\text { 1) Running - starts running the obstacle course. } \\
\text { 2) Jump } 1.5 \mathrm{~m} \text { mat - running and then jumping over a } 1.5 \mathrm{~m} \text { mat. } \\
\text { 3) Stairs - circles a pylon and then turns to run up and down a set of stairs. Circles a pylon and runs up and down the stairs again. } \\
\text { 4) Hurdles } 0.45 \mathrm{~m} \text { - jumps over two hurdles } 0.45 \mathrm{~m} \text { high. } \\
\text { 5) Vault jump; } 0.9 \mathrm{~m} \text { railing - lands the vault jump. Alternate front/back on each lap. } \\
\text { 2. Physical control push and pull - completes the push and pull. ( } 180 \text {-degree arcs, } 6 \mathrm{x}) \\
\text { 3. Torso bag carry (carry to safety) - Picking up a red bag }(36 \mathrm{~kg} \text { ) and lifts the bag. Starts to carry it and walks toward } 15 \mathrm{~m} \text { an orange pylon. } \\
\text { Circles the pylon and sets down the bag. (This section is not timed) }\end{array}$ \\
\hline $\begin{array}{l}\text { Germany } \\
\text { BPOL }\end{array}$ & $\begin{array}{l}\text { 1. Coordination test } \\
\text { 1) Roll forward over the mat. } \\
\text { 2) Rotate to the left of the medicine ball. } \\
\text { 3) Jump over obstacles. } \\
\text { 4) And then crawled through. (The same sequence applies to the second and third obstacles. To run over the mat.) } \\
\text { 2. } 10 \mathrm{~m} \text { Shuttle run ( } 4 \times 10 \mathrm{~m}) \\
\text { 3. } 12 \text {-minute run }\end{array}$ \\
\hline $\begin{array}{l}\text { France } \\
\text { Police } \\
\text { Nationale }\end{array}$ & $\begin{array}{l}\text { 1. Circulation exercise test ( } 10 \text { events) } \\
\text { 1) Wear A weighted bag - carried out by walking over } 20 \mathrm{~m} \text {. } \\
\text { ( } 25 \mathrm{~kg} \text { for women, } 40 \mathrm{~kg} \text { for men) (This section is not timed) } \\
\text { 2) Push-up ( } 3 \text { movements for women, } 5 \text { movements for men) } \\
\text { 3) Crossing of } 3 \text { hurdles ( } 60 \mathrm{~cm} \text { for women, } 70 \mathrm{~cm} \text { for men) } \\
\text { 4) Balance on a balance beam ( } 1 \mathrm{~m} \text { height, } 5 \mathrm{~m} \text { long) } \\
\text { 5) Leaps the zigzag hoops. } \\
\text { 6) Alternate step on both feet. } \\
\text { 7) Crossing barriers } \\
\text { 8) Crossing horizontal ladder ( } 2 \mathrm{~m} \text { for women, } 3.5 \mathrm{~m} \text { for men) } \\
\text { 9) Crawl under a device forming a tunnel. } \\
\text { 10) Slalom race }-45 \mathrm{~m} \text { zigzag running } \\
\text { 2. } 20 \mathrm{~m} \text { Shuttle }(4 \times 20 \mathrm{~m} \text { ) }\end{array}$ \\
\hline
\end{tabular}

NYPD, New York City Police Department; RCMP, Royal Canadian Mounted Police; BPOL, Bundespolizei 
업무 실행의 가능 여부를 확인할 수 있는 장점을 가진 순환식 체력검사를 통해 경찰 공무원을 선발하고 있다.

네 개의 국가에서 시행되고 있는 순환식 체력검사 시 험에 대한 소개는 <Table 2>과 같다.

미국 뉴욕시 경찰 $($ New York City Police Department; NYPD)[12]과 캐나다 연방경찰(Royal Canadian Mounted Police; RCMP)[13]에서는 경찰 공무원 채용 시 순환식 체력검사를 채택하고 있으며, 독 일 연방경찰(Bundespolizei; BPOL)[14]과 프랑스 국가 경찰(Police Nationale)[15]은 종목식 체력검사와 순환 식 체력검사 방법을 병행하여 운영하고 있다.

미국 뉴욕시 경찰(NYPD) 채용 시 체력검사는 순발 력과 민첩성, 심폐지구력과 근파워를 요구하는 항목들 로 검사가 진행되며, 남녀 모두 동일하게 제한 시간 4 분 28초 이내에 완수해야 한다[16]. NYPD의 체력검사 와 우리나라의 개정된 체력검사 방식은 순환식 형태로 매우 유사하게 구성되어 있다. 캐나다 연방경찰(Royal Canadian Mounted Police, RCMP) 채용 시 체력검사 (Physical Abilities Requirement Evaluation; PARE) 의 항목들은 순발력과 민첩성, 심폐지구력과 근지구력, 그리고 코어 근력과 배근력을 비롯한 전신 근력이 필요 하다. 남녀의 평가 기준은 동일하며, 1 번과 2 번 항목은 제한 시간 4 분 45 초 이내에 완수해야 하고 2 분 휴식을 진행 후에는 시간 계측 없이 3 번 항목을 진행한다[17]. 독일 연방경찰(Bundespolizei; BPOL)의 체력검사[18] 는 혼합된 형식으로, 성별 및 연령에 따른 차등 기준으로 평가한다. 순환식 체력검사 방법을 사용하여 신체 조정 능력에 대한 평가를 진행하며, 종목식 체력검사에서는 민첩성과 심폐지구력 요구하는 검사로 진행하고 있다. 독일과 마찬가지로 프랑스 국가경찰(Police Nationale) 채용에서도 혼합된 형식의 체력검사를 진행하고 있다. 이 중 순환식 체력 검사는 근력, 근지구력, 심폐지구력, 스피드, 민첩성, 순발력 항목을 측정하는 전체 10가지 코스로 구성되어 있다. 평가 시에 남녀의 기준 시간은 동일하나, 일부 항목에 있어 남녀에 따라 무게나 횟수, 길이 등 평가 기준의 차이가 존재한다[19].

\section{개정된 경찰공무원 체력검사를 위한 기능성 체력 훈련 프로그램}

기능성 체력 훈련 프로그램은 경찰공무원 채용 시 새
롭게 도입되는 5단계 순환식 체력검사 제도에 맞게 각 단계별로 개발하였으며, FITT 원칙에 따라 프로그램을 구성하였다. 경찰공무원 채용과 간부 후보생 선발 자격 에 응시하는 대상자들은 본 연구에서 제시하는 프로그 램을 통한 꾸준한 훈련으로 체력을 증진시키고 수행능 력을 높여 새롭게 도입되는 체력검사 시험을 통과하는 데 유용한 방법으로 사용될 수 있을 것으로 확신한다. 또한 개정된 체력검사 시험을 통과해 선발된 경찰공무 원은 직무에 적합한 체력을 갖춰 경찰 업무를 보다 더 효율적으로 수행해 나갈 것으로 기대한다. 기능성 체력 훈련 프로그램은 <Table 3 >과 같다.

첫 번째 체력검사 종목인 장애물 코스 달리기를 위 한 기능성 체력 훈련 프로그램은 심폐지구력을 위한 지 구성 달리기(Table 3. 1-(1))와 민첩성, 순발력, 협응력, 반응속도를 향상시킬 수 있는 스프린트 및 민첩성 훈 련(Table 3. 1-(2))이다. 지구성 달리기는 여유 심박수 (Heart rate reserve; HRR)의 60\% 이상 고강도로 최 소 30분 이상 주 3-5회 실시하는 훈련 방법이며, 점진 적으로 거리를 늘려서 훈련한다. 스프린트 및 민첩성 훈 련은 $20 \mathrm{~m}$ 편도를 전력 질주하고, 돌아오는 $20 \mathrm{~m}$ 편도는 $2 \mathrm{~m}$ 마다 놓인 콘 사이로 지그재그 달리기를 실시하며 왕 복 $40 \mathrm{~m}$ 를 10 세트 진행한다.

장애물 코스 달리기 종목 내의 세부 항목인 매트 넘 기를 위한 훈련 프로그램은 순발력과 협응력을 기를 수 있는 턱 점프(Table 3. 1-(3)) 동작은 무릎을 최대한 가 슴 쪽으로 붙여 점프하도록 하며, 중량 조끼나 중량 밴 드를 사용하여 강도를 높이는 것을 권장한다. 협응력을 향상시키기 위한 워킹 런지(Table 3. 1-(4)) 동작은 한 쪽 다리당 10 회씩 총 20 회 진행한다. 강도를 높일 시 덤 벨 또는 케틀 벨 등 무게를 추가한다.

장애물 코스 달리기 종목 내 세부 항목인 계단 오 르내리기 체력검사는 민첩성과 순발력을 평가하기 위 한 것으로, 기능성 체력 훈련 프로그램에서는 전신지구 력과 민첩성을 위한 하버드 스텝(Table 3. 1-(5)) 동작 과, 민첩성과 순발력을 위한 스텝 박스 점프(Table 3. 1-(6) 동작으로 구성하였다. 스텝박스가 없을 시 계단 에서 진행 가능하며 빠른 속도로 훈련을 진행하도록 한 다. 메트로놈과 같은 박자에 맞추어 훈련을 할 수 있으 며 강도를 높일 시에는 중량 조끼나 중량 밴드를 사용 하는 것을 권장한다.

장애물 코스 달리기 내에 포함되어 있는 허들넘기 
Table 3. Functional physical training program for a new police officer employment

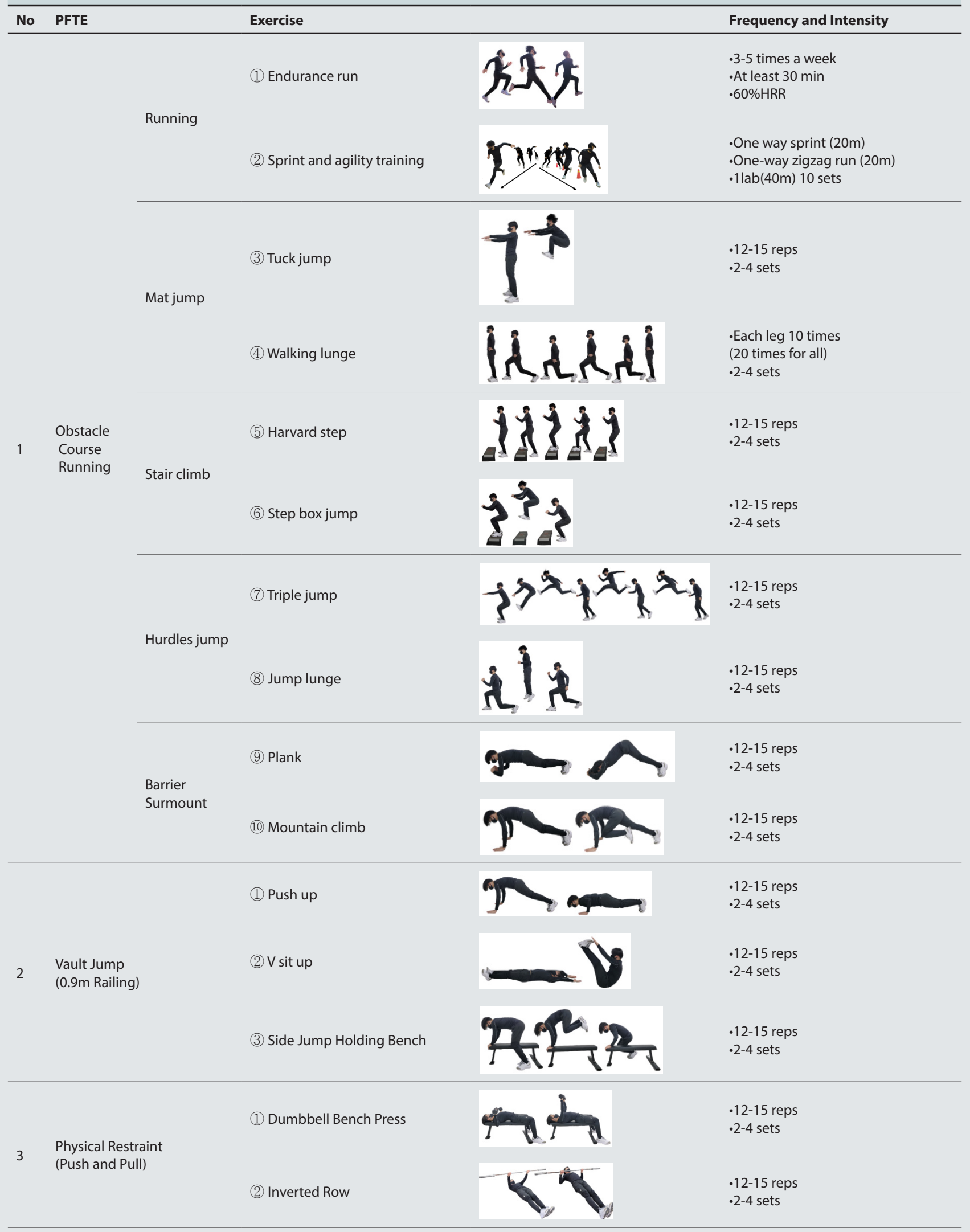




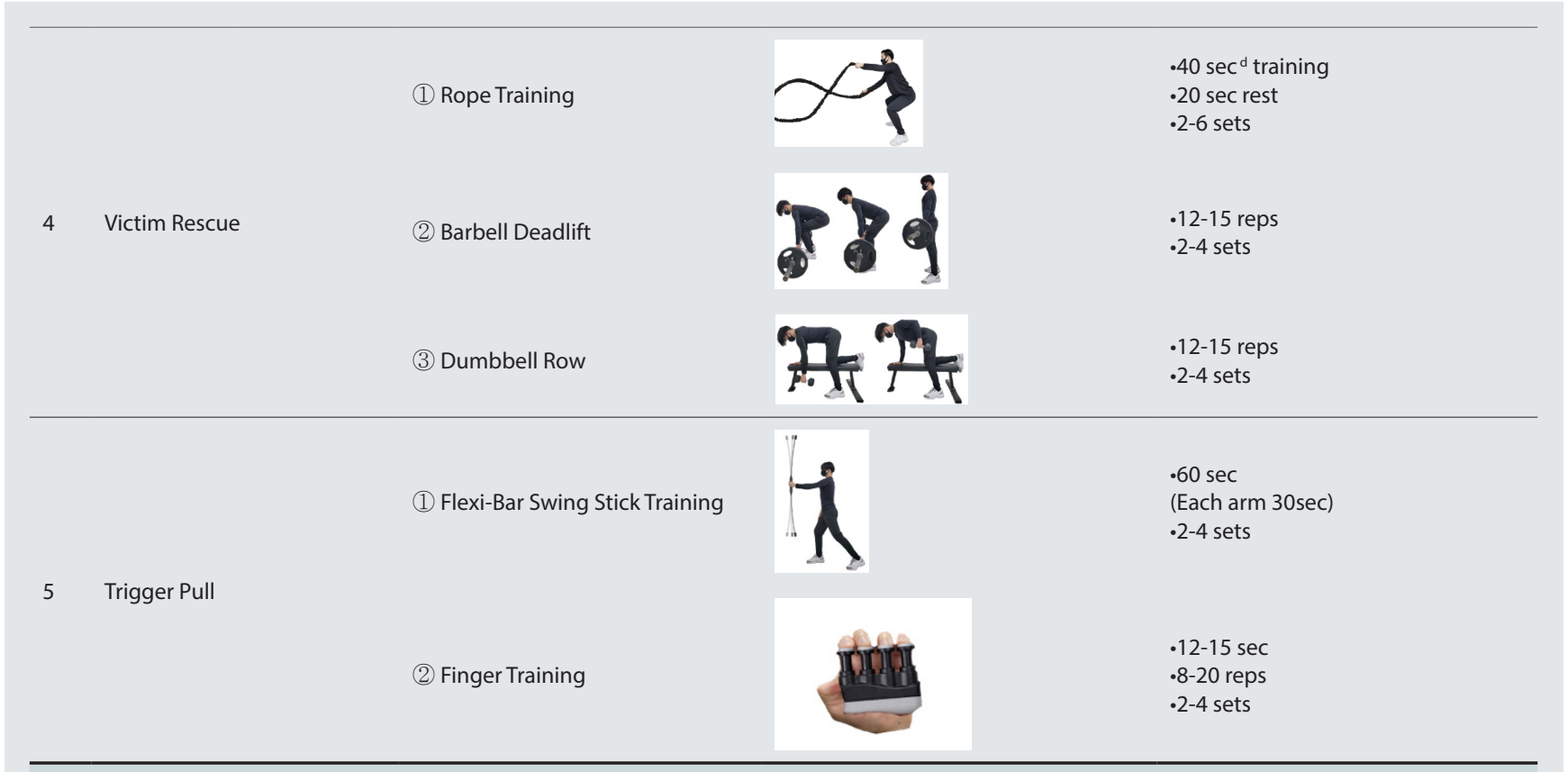

PFTE, Physical Fitness Training Events; Min, Minute;\%HRR, Percent Heart Rate Reserve; Reps, Repetitions; Sec, Seconds

세부 항목을 위한 체력 훈련으로는 민첩성, 스피드, 협 응력, 순발력을 향상시킬 수 있는 3단 뛰기(Table 3. 1-(7) 동작과 순발력과 협응력을 강화할 수 있는 점프 런지(Table 3.1-8) 동작으로 구성하였다. 점프 런지 의 경우 팔 동작은 허리 손 - 달리기 자세 - 만세 순으 로 진행하여 동작의 변화를 주거나, 중량 조끼나 중량 밴드 등을 착용하여 강도를 조정할 수 있다.

장애물 코스 달리기 종목의 마지막 세부 항목으로 1 회 진행하는 장벽 넘기는 근력, 유연성, 순발력, 협응력 이 요구된다. 장벽을 넘기 위한 상지와 하지 근력이 모 두 중요하지만 단단하게 지탱해 줄 수 있는 코어 근력 이 가장 중요하다. 기능성 체력 훈련 프로그램은 코어 를 위한 플랭크(Table 3. 1-9) 동작과 협응력, 순발력, 유연성이 모두 향상될 수 있는 마운틴 클라이밍 (Table 3. 1-(10) 동작으로 구성하였다. 이때 플랭크의 강도를 높일 시에는 기본 플랭크 동작에서 팔은 고정한 채, 엉 덩이를 위로 들어 다운 독(Downward Facing Dog) 자 세 후 다시 원래 자세로 돌아오는 것을 반복하여 진행 할 수 있다. 추가적으로 플랭크 동작 후 버피 동작을 연 결하여 진행하는 것을 추천한다. 마운틴 클라이밍의 강 도를 높일 경우, 하지에 중량 밴드를 사용하거나 보수를 뒤집어 놓은 상태에서 동작을 진행한다.

두 번째 종목인 장대 허들 넘기는 기본적으로 장대를
넘고 난 후 매트에서 엎드리거나 등을 대고 누운 후 일 어나는 동작에서 근체력과 코어를 요구한다. 체력검사 를 위해 푸시업(Table 3. 2-(1)) 동작과 V 싯업(Table 3. 2-(2) 동작으로 구성하였으며, 민첩성과 협응력이 요 구되는 해당 종목의 동작을 훈련하기 위해 벤치 의자 잡 고 사이드 점프(Table 3. 2-(3))를 진행하도록 한다. 기 본 푸시업 동작이 익숙해지면 푸시업 바를 이용하여 장 대 허들을 잡는 것과 같이 그립을 잡아 동작을 진행할 수 있으며, 푸시업 바가 없을 시에는 인클라인 푸시업으 로도 대체 가능하다. 강도를 높이기 위해서는 푸시업과 벤치 의자 잡고 사이드 점프는 중량 조끼를 착용하고, $\mathrm{V}$ 싯업은 발목에 중량 밴드 착용하거나 메디신 볼을 사 용하여 진행한다. 각 동작 당 반복 횟수는 12-15회 실 시하고 2-4세트로 강도를 늘려나간다.

세 번째 종목인 밀기-당기기 검사는 신체 저항 기 구를 사용하여 근체력을 요구하는 종목으로 덤벨 벤치 프레스(Table 3. 3-(1)) 동작 후, 인벌트 로우(Table 3. 3-(2) 동작을 하는 것을 추천한다. 강도를 높일 때는 덤벨 벤치 프레스는 중량을 늘리고, 인벌트 로우는 중 량 조끼를 착용한다. 덤벨 벤치 프레스는 체스트 프레 스 동작으로 대체 가능하다. 세 번째 종목을 위한 각 동 작 당 반복 횟수는 12-15회 실시하고 2-4세트로 강도 를 늘려나간다. 
네 번째 종목인 인명 구조하기는 전신 근력을 요구하 며, 기능성 체력 훈련 프로그램에서는 로프 훈련(Table 3. 4-(1)과 바벨 데드리프트(Table 3. 4-(2) 동작 및 덤 벨 로우(Table 3.4-(3) 동작으로 구성하였다. 로프 훈 련의 경우 초보자는 30초 운동, 20초 휴식, 2-3세트로 시작하여 점진적으로 60초 운동, 30초 휴식 4-6세트로 늘려 나간다. 바벨 데드리프트를 진행할 수 없을 시에는 백 익스텐션 동작으로 대체 가능하며, 덤벨 로우 동작을 진행할 수 없을 시에는 바벨 로우 동작이나 시티드 로우 동작으로 대체 가능하다.

다섯 번째 종목인 방아쇠 당기기는 팔과 손가락의 근 지구력이 요구되는 종목이다. 다른 종목에 비해 섬세한 동작을 요구하는 만큼 소도구의 사용이 필요하여 흔들 림에도 팔을 단단하게 유지하기 위한 스윙 플렉스 바 훈 련(Table 3. 5-(1))과 손가락 당기기용으로 제작된 소도 구 또는 고무 링을 사용한 손가락 훈련(Table 3. 5-(2)) 으로 구성하였다. 스윙 플렉스 바는 오른팔 30초, 왼팔 30 초로 총 60 초간 팔꿈치를 편 상태에서 흔들리는 바 를 잡아 최대한 움직이지 않고 버티며 진행하고, 강도는 점진적으로 한 팔당 30-60초로 시간을 늘려 조절한다. 손가락 훈련의 경우 손가락 당기기를 12-15초 8-20회 로 시작하여 점진적으로 50회까지 늘려 나가는 것을 추 천한다. 새롭게 개정되는 순환식 체력검사를 4 분 40 초 내에 통과할 수 있도록 경찰공무원 지원자와 관련 대상 자들의 체력 증진을 목적으로 개발된 것으로 기능적 체 력 훈련 프로그램은 주 3-5회 정도 60-90분 정도 반복 훈련을 통해 경찰공무원 지원자들의 체력 향상으로 선 발 과정에 긍정적인 영향을 미칠 것으로 판단되며 선발 된 경찰공무원들은 개인의 안전 뿐만 아니라 경찰 직무 를 수행하는데 있어서도 매우 바람직인 영향을 미칠 것 으로 사료된다.

\section{결론}

여러 국가에서 경찰공무원의 직무에 맞는 신임 경 찰공무원 체력검사 제도를 도입함으로써 보다 양질의 경찰공무원 채용과 이들이 현장에 투입되었을 때 직무 활동이 더 효율적일 수 있을 것으로 사료된다. 본 연구 에서는 경찰공무원 채용과 선발을 위해 새롭게 도입되 는 순환식 체력검사 제도를 살펴보고 개정된 체력검사 에 통과하여 경찰의 직무에 최적화된 경찰공무원이 선
발될 수 있도록 기능성 체력 훈련 프로그램을 제시하였 다. 직무에 적합한 능력과 강인한 체력을 바탕으로 선 발된 경찰공무원들이 치안과 범죄 및 여러 위해에 대응 하여 우리나라가 세계 속 가장 안전한 나라로 자리매김 하기를 고대한다.

\section{Conflicts of Interest}

The authors declare no conflict of interest.

\section{Funding}

This research was supported by Soonchunhyang University Research Fund of 2021.

\section{References}

1. Police officers. Encyclopedia of Korean culture. 1995; http://encykorea.aks.ac.kr/Contents/Item/E0002953 (Accessed Nov 02, 2021)

2. Korean National Police Agency. Korean national police agency statistics. https://www.police.go.kr/www/open/ publice/publice02.jsp.

3. Park IH. Establishment of physical fitness standards for the integrated selection of male and female candidates for Korean national police university and police executive candidates: Research report. Seoul National University Institute of Sport Science; 2018.

4. Kang HS. A study on the problems of the open competition policemen test and their solutions. Seoul, Dongguk University; 2011.

5. Bang HS. Development of task-related physical fitness tests for police officers and verification of the validity and reliability. Yongin, Kyung Hee University; 2010.

6. Silk A, Savage R, Larsen B, Aisbett B. Identifying and characterizing the physical demands for an Australian specialist policing unit. Applied Ergonomics. 2018; 68:197-203.

7. Korean Law Information Center. Decree on the Appointment of Police Officer. https://www.law.go.kr/ LSW/main.html . (Accessed Nov 03, 2021)

8. Bonneau J, Brown J. Physical ability, fitness, and police 
work. J Clin Forensic Med. 1995; 2(3):157-164.

9. Korean National Police Agency. Rules of the Decree on the Appointment of Police Officer. https://www.police.go.kr . Accessed Nov. 03, 2021)

10. Kim SW. Problems and Development of Police Officials' Physical Fitness Tests. Journal of the Korea Contents Association. 2019;19(8):609-619.

11. Kim HB, Kim EJ. The development plan is through the problem of physical strength evaluation and physical examination for police officers. Korean Police Studies Review. 2014; 13(3):31-52.

12. New York City Police Department. https://www1.nyc.gov/ site/nypd/index.page (Accessed Sep 08, 2021)

13. Royal Canadian Mounted Police.. https://www.rcmp-grc. gc.ca/en (Accessed Sep 08, 2021)

14. Bundespolizei. https://www.bundespolizei.de (Accessed Nov 10, 2021)

15. France Nationale Police. https://www.police-nationale. interieur.gouv.fr/ (Accessed Nov 10, 2021)

16. New York City Police Department Job standards test. https://youtu.be/U5QlJpz5skI (Accessed Sep 08, 2021)

17. Royal Canadian Mounted Police. Police Officers Physical Abilities Test. https://youtu.be/N-yb9oUSgx4 (Accessed Sep 08, 2021)

18. Bundespolizei Physical fitness test. https://youtu.be/ wbJ5IAHsYpQ (Accessed Nov 10, 2021)

19. France physical fitness test. https://www.youtube.com/ watch?v=PBW2NfZxvg0 (Accessed Nov 10, 2021) 